\title{
The Role of National Cultures in Foreign Subsidiaries' Practices Applied to Support Knowledge Flow within MNCs
}

\begin{abstract}
The main goal of this paper is to contribute to a better understanding of intercultural aspects affecting cross-border knowledge flow in MNCs by recognizing similarities and differences pertaining to the practices supporting such flow in 200 Polish-based subsidiaries grouped into clusters according to 'national' origin of parentcompany2. Analyses of data collected in 2014 encompassed descriptive statistics, and in-pair comparisons. Significant differences were identified by a Kruskall-Wallis test, ChiSquare Test, and a UMW test. Results suggest that such a flow was supported mainly by discussions via ICT and access to databases. Significant differences between clusters were found for usage of e-learning programs, e-mentoring/e-coaching, virtual teams, and HRM practices.
\end{abstract}

Key words: cross-border knowledge flow, subsidiaries, country clusters

\section{Introduction}

A distinctive feature of the new economy is a key role of knowledge in the development of organizations. However, the essence of this knowledge is understood differently in various cultures [Zhu Z. 2004; Nonaka I. et al 2008; Despite the lack of its commonly accepted definition, it is often argued that knowledge flow relies on social interactions between individuals who are able/ willing to share their experience, teach others, and learn from them [Pauleen D.

\footnotetext{
1 purgalj@uek.krakow.pl

2 Research was financed by the National Science Centre, based on decision No. DEC2012/07/D/HS4/00741.
} 
et al 2007, pp.12-13]. As the perception of knowledge properties differs across cultures, various mechanisms are supposed to support its diffusion, including ICTbased tools [Bonache J., Dickmann M. 2006; Sparrow P. 2006]. Nevertheless, the effectiveness of using these tools is problematic, particularly when establishing positive and intense relationships across borders is at stake, and thus face-to-face contact remains irreplaceable in such occasions [Pauleen D. et al 2007, p.3].

Nurturing knowledge flow is a challenging issue for contemporary companies [Nonaka I. et al 2008]. The extent of difficulty when managing such flows is even greater for MNCs due to cultural embeddedness of knowledge (itself), and KM practices [Nonaka I., Toyama R., 2003]. As re-usage of know-how in many locations is a tempting option for international expansion, a growing interest of practitioners and researchers is addressed to development of work environment and mechanisms that facilitate cross-border knowledge flow (CBKF) [Bonache J., Dickmann M. 2006].

However, implementing such practices have not any longer been regarded as solely headquarters' domain. First, because MNCs develop and pursue strategies that affect HQ-subsidiaries relationships, in a diverse manner, which reflects their own "solution" of a global integration - local responsiveness dilemma [Evans P. et al. 2011]. Second, because of differences in subsidiaries' activity within vertical and lateral knowledge flows [Gupta A.K., Govindarajan V. 2000]. Thus, the way in which a subsidiary takes part in CBKF would rather reflect its specifics shaped by the local culture, but the impact of mother-company country-of-origin cannot be ignored [Noorderhaven N., Harzing A.-W. 2003, pp. 47-48].

Given the cultural embeddedness of KM practices, and the complexity of subsidiaries' dual cultural embeddedness together with their changing activity in CBKF, we should consider the aforementioned practices $^{3}$ in their intercultural context characterized by tension between daughter- and mother-companies specifics with an emphasis on their national backgrounds.

Accordingly, this papers seeks to extend our understanding of intercultural aspects affecting intracorporate cross-border knowledge flow at the subsidiary level. In particular, it is aimed to find similarities and differences pertaining to internal and cross-border practices supporting CBKF in 200 Polish-based subsidiaries grouped in country clusters according to 'national' origin of MNCs to which they belong. With regards to these practises it is assumed that differences between clusters provide an argument for country-of-origin effect ${ }^{4}$, while homogeneity and

3 These practices, also called mechanisms, are defined here as organizational arrangements used by subsidiary to enable/facilitate unidirectional (e.g. instructing, counselling), and multidirectional flows (i.e. knowledge sharing) in passive (i.e. access to structured, explicit knowledge) or interactive manner, directly (by personal contact) or indirectly (via ICT).

4 It might reflect an ethnocentric approach of MNCs or their focus on global integration . 
similarity to practices observed in Polish companies by other researches correspond with local responsiveness of MNCs operating in Poland ${ }^{5}$.

\section{Current state of knowledge}

Organizational practices in MNCs vary across countries, since they are affected by cultural and institutional ${ }^{6}$ environments [Kostova T. 1999; Zhu Z. 2002; Harzing A.-W., Sorge A.M. 2003]. Yet, as long as an academic debate on divergenceconvergence in managing MNCs goes on, no consensus pertaining to the relevance of these influences can be reached [Glińska-Neweś A. 2007, p.145-146].

Therefore, examining CBKF through intercultural lens allows us to understand the complexity of this phenomenon, which is a prerequisite for improvement of managerial activities aimed to achieve/maintain competitive advantage based on knowledge assets [Javindan M. et al. 2005]. When considering the cultural context of CBKF, some researchers chose a holistic approach, trying to grasp whole differences and similarities between cultures from which the participants originate [e.g. Kostova T. 1999, Li et al. 2007]. Others applied selected cultural dimensions, e.g. In-Group and Institutional Collectivism, Power Distance, and Uncertainty Avoidance, as they directly relate to the most important facets of CBKF, i.e. openness and trust in lateral and hierarchical relationships, ambiguity of communicating, teamwork, establishing/nurturing relationships within and outside the group, affiliation and loyalty to a community [e.g. Javindan D.J. et al 2005, pp. 63-71; Lin, C.Y., 2006, pp. 25-29; Glińska-Neweś A. 2007, pp.158-161].

Regarding CBKF between dispersed units of MNCs, Dickmann and MüllerCarmen [2006] suggest that companies rely on bureaucratic methods based on formal roles and procedures (e.g. reporting, databases, repositories and Intranetbased tools), social mechanisms based on interactions between employees of various business units (e.g. corporate communities of practice, global teamwork), and personal - based on direct contacts ${ }^{7}$ (e.g. between international assignee and host staff, coach and trainee). According to Sparrow [2006, pp.128-133], not only do these mechanisms support transfer of know-how, but they also contribute to a creation of new knowledge, yet to a different degree. Furthermore, he considers their effective usage in KM sub-processes as directly interrelated with HRM activities.

5 Another explanation refers to a convergence of practices, yet due to the scope of this study (only Poland-based entities) any of these explanations cannot be satisfactorily confirmed.

${ }^{6}$ Institutional environment, regarded as a component strictly related to culture, exerts influence through establishing and maintaining a regulatory framework, defining desired goals and means appropriate to achieve them, and through affecting individual beliefs and opinions by institutions [Noorderhaven N., Harzing A.-W. 2003, p.57].

It should be noted however, that this distinction between social and personal mechanisms is rather blurred, as some mechanism e.g. common international trainings or incorporating international assignees into global teams involve at the same time: social interactions and personal contacts. 
Similarly, Polish academics linked some of the above mechanisms to several KM sub-processes, such as development, dissemination, and application of knowledge [e.g. Stankiewicz M.J. 2006, pp.354-363, Glińska-Neweś A. 2007, pp.171-172; Gruszczyńska-Malec G., Rutkowska M. 2013, pp.208-210]. Moreover, like Sparrow, they emphasized the role of HRM practices in creating an environment supportive for knowledge diffusion, especially through direct contacts.

It should be noted, that empirical studies dedicated to knowledge diffusion in Poland-based companies have not yet encompassed CBKF and its mechanisms. Among these sparse scientific papers/monographs showing some related aspects one can find works on: transcorporate communication [Stor M. 2011], cultural problems concerning relationships between Polish and foreign employees in subsidiaries [Rozkwitalska M. 2011; Przytuła S. 2014], knowledge transfer via expatriation [Purgak-Popiela J. 2015]. Summing up, this study addresses the gap in the extant research, due to the nature of considered knowledge flow, its mechanisms, and the specifics of organizations subjected to analyses.

\section{Materials \& Methods}

Data stem from a survey carried out in 2014, and based on structured questionnaires addressed to senior managers (in charge of knowledge transfer) employed in 200 foreign Poland-based subsidiaries, who acted as single informants. The sample was drawn by random sampling from a pool of subsidiaries ${ }^{8}$ established as companies with $100 \%$ foreign ownership before 01.01 .2012 , at response rate of $13 \%{ }^{9}$. Characteristics of sample is displayed in Table 1 . Subsidiaries were grouped, according to their parent company's country-of-origin, into country clusters, i.e. categories adapted from the GLOBE project [House R.J. et al., 2004]. Cluster 'Anglo' consisted of entities belonging to MNCs from England, Ireland, USA, Canada, and Australia; Latin European encompassed France, Italy, and Spain; Nordic Europe comprised Sweden, Norway, Finland and Denmark; Germanic Europe covered Germany, Austria and Netherlands; whereas Eastern Europe was represented by Hungary, Slovakia and Czech Republic. Japan and South Korea formed Confucian Asian cluster, while India and Indonesia - Southern Asian. Middle Eastern cluster consisted of Turkey and Saudi Arabia ${ }^{10}$. No significant difference between these clusters was found in terms of a subsidiaries' age, size, sector of activity, and mode of establishment.

\footnotetext{
8 To prepare sampling frame REGON and GUS data were used.

9 To control non-response bias early and late respondents were compared with respect to all considered characteristics of subsidiaries. No significant difference was found.

10 It should be noted that within the original Middle East cluster Saudi Arabia was not included, however, given its geographical and cultural proximity to Kuwait and Qatar belonging to this group it is considered as a member of this society in this cluster.
} 
Table 1. Characteristics of sample: Poland-located subsidiaries grouped in country clusters

\begin{tabular}{|c|c|c|c|c|c|c|c|c|c|c|c|c|}
\hline \multirow[t]{2}{*}{$\begin{array}{l}\text { Cluster } \\
(N)\end{array}$} & \multirow[t]{2}{*}{$\begin{array}{l}\text { Age* } \\
\text { mean }\end{array}$} & \multicolumn{3}{|c|}{$\begin{array}{l}\text { Size of } \\
\text { employment } \\
* * \text { ( } \% \text { of } \\
\text { oroup) }\end{array}$} & \multicolumn{6}{|c|}{$\begin{array}{l}\text { Sector of activity*** } \\
\text { ( } \% \text { of group) }\end{array}$} & \multicolumn{2}{|c|}{$\begin{array}{l}\text { Establishment } \\
\text { mode**** }\end{array}$} \\
\hline & & $49-$ & $\begin{array}{l}\frac{{ }^{2} 0-}{50-} \\
249\end{array}$ & $\begin{array}{l}250 \\
-\ldots\end{array}$ & $\begin{array}{l}\text { Indu- } \\
\text { stry }\end{array}$ & $\begin{array}{l}\text { Tra- } \\
\text { de }\end{array}$ & $\begin{array}{l}\text { Constru- } \\
\text { ction }\end{array}$ & $\begin{array}{l}\text { Finan. } \\
\text { servic. }\end{array}$ & $\begin{array}{l}\text { Transp./ } \\
\text { Commun. }\end{array}$ & $\begin{array}{l}\text { Other } \\
\text { services }\end{array}$ & $\begin{array}{l}\text { brown } \\
(\%)\end{array}$ & $\begin{array}{l}\text { green } \\
(\%)\end{array}$ \\
\hline $\begin{array}{l}\text { Anglo } \\
\text { (33) }\end{array}$ & 13.8 & 6 & 51 & 42 & 51 & 12 & 0 & 0 & 3 & 33 & 51 & 48 \\
\hline Latin E. & 13.7 & 31 & 31 & 37 & 54 & 9 & 14 & 3 & 6 & 14 & 46 & 54 \\
\hline $\begin{array}{l}\text { Nordic } \\
(28)\end{array}$ & 13.4 & 32 & 39 & 27 & 36 & 29 & 7 & 11 & 4 & 14 & 43 & 57 \\
\hline $\begin{array}{l}\text { Germanic } \\
\text { (86) }\end{array}$ & 14.8 & 27 & 46 & 27 & 38 & 34 & 7 & 2 & 5 & 14 & 31 & 67 \\
\hline $\begin{array}{l}\text { Eastern } \\
\text { E. } \\
(5)\end{array}$ & 12.8 & 60 & 20 & 20 & 80 & 20 & 0 & 0 & 0 & 0 & 20 & 80 \\
\hline South. A. & 6.0 & 33 & 67 & 0 & 67 & 0 & 0 & 0 & 0 & 33 & 33 & 67 \\
\hline $\begin{array}{l}\text { Conf. A } \\
\text { (9) }\end{array}$ & 10.4 & 44 & 22 & 33 & 56 & 33 & 0 & 0 & 0 & 11 & 11 & 89 \\
\hline $\begin{array}{l}\text { Mid. East } \\
\text { (2) } \\
\text { All }\end{array}$ & $\frac{17.5}{13.9}$ & $\frac{0}{26}$ & $\frac{100}{43}$ & $\frac{0}{31}$ & $\frac{50}{45}$ & $\frac{0}{24}$ & $\frac{0}{6}$ & $\frac{0}{3}$ & $\frac{0}{4}$ & $\frac{50}{17}$ & $\frac{0}{37}$ & $\frac{100}{63}$ \\
\hline
\end{tabular}

*insignificant difference between clusters (ANOVA, $\mathrm{F}=1.636$, df:7, $\mathrm{p}=0.127$ )

** insignificant difference between clusters in proportions of companies with small, medium or large number of employees $\left(X^{2}=19.282\right.$,

$\mathrm{df}: 14, \mathrm{p}=0.154)$

***insignificant difference in proportions of companies operating within distinguished sectors $\left(\mathrm{X}^{2}=38.584\right.$, df:35, $\mathrm{p}=0.311)$

**** insignificant difference in proportions of companies established as greenfield or brownfield investments $\left(\mathrm{X}^{2}=10.050, \mathrm{df}: 7, \mathrm{p}=0.186\right)$

To identify mechanisms facilitating cross-border knowledge flow, 16 statements were applied in questionnaires, of which 3 concerned internal HR practices, and 13 characterized diverse methods directly supporting CBKF. Informants were asked to estimate the extent to which each of these items refer to the subsidiaries they work for (in $0-5$ point scale, from $0=$ not at all, $1=$ very small extent, to 5 $=$ very high extent). All these items drew on previous research dedicated to KM in Poland [Glińska-Neweś A. 2007, Kordel P. at al. 2010, Płoszajski P. (ed.) 2011, Gruszczyńska-Malec G., Rutkowska M. 2013] and literature on CBKF. The above list covered:

- mechanisms providing access to structured knowledge from diverse parts of an MNC: (1) databases of good practices, (2) other repositories of knowledge resources, and (3) expert systems ${ }^{11}$, (4) e-learning programs;

11 Defined as computer programs reflecting the decision-making processes by an expert 
- mechanisms offering virtual interactions between geographically dispersed participants, which are compulsory for (5) international virtual teams, (6) crossborder e-mentoring/e-coaching (when a coach/mentor represents other location than a trainee);

- or voluntary ${ }^{12}$ in case of (7) corporate communities of practice, (8) discussions via ICT, (9) consulting with professionals from corporate database of experts;

- mechanisms ensuring direct interactions between participants representing diverse locations: (10) corporate international group trainings, (11) cross-border teams located abroad, (12) sending employees individually for international assignments, (13) mentoring/coaching (when a coach/mentor represents other location than a trainee);

- internal HRM policies and practices encouraging employees of a given subsidiary to share their know-how with others/teach them through direct interactions by: (14) incorporating such attitudes in the selection process, (15) including the above behaviours in employee appraisal and rewarding systems; and (16) recognizing knowledge sharing behaviours as priority domain of employee development via trainings/other HRD initiatives.

Empirical material collected by these questionnaires was subjected to analyses aimed to determine the extent to which each of these mechanisms occurred in the sample (on the basis of median values), and then to identify these solutions, for which results were the most diverse (on the basis of interquartile range). Next, a KruskallWallis test was performed to find out these practices, for which differences between clusters were significant. As this test does not answer the question which cluster differs significantly from the rest ${ }^{13}$, in-pair comparisons based on contingency tables (together with Chi-Square Test) and a UMW test were used.

\section{Results}

Results shown in Table 2 suggest that subsidiaries of MNCs operating in Poland utilized two groups of mechanisms facilitating CBKF: discussions via ICT and access to databases $\left(\mathrm{Q}_{2}=4\right)$. With respect to the latter, the interquartile range was low, thus half of the entities reported similar levels of their usage. Slightly less popular were the mechanisms facilitating direct relationships (i.e. individual assignments, working in cross-border teams, international trainings, cross-border mentoring/coaching), and more 'technologically advanced' expert systems as well

(human being) that allow to solve technical problems through contained therein knowledge base and rules of inference.

12 Notion "voluntary" means, that these interactions are not imposed by the form of work organization, but can be initiated by employees searching for knowledge outside their home unit.

13 At this stage of analysis it was necessary to create binary variables, and then compare results for two groups of subsidiaries: belonging to a given cluster (value $=1$ ), and not belonging to this cluster $($ value $=0)$. 
as virtual corporate communities of practice. For these mechanisms median values obtained moderate levels. However, worth noting is a significant dispersion of results pertaining to communities of practice and cross-border coaching/mentoring (IQR $=3$ ). The least popular mechanisms were cross-border e-coaching/e-mentoring, e-learning programs and virtual teams $\left(Q_{2}=2\right)$, yet the results for the last two were strongly differentiated $(\mathrm{IQR}=3)$.

As for internal HRM practices, to a rather high extent they supported behaviours aimed at knowledge sharing/teaching $\left(Q_{2}=4\right.$ for recruitment, appraisal/rewarding, HRD).

Table 2. Mechanisms supporting CBKF in subsidiaries grouped in clusters according to 'nationality' of their parent-companies.

I: proportion of subsidiaries within the cluster declaring at least rather high extent (in \%) II: average level: $\mathrm{Q}_{2}$ in clusters (in $0-5$ point scale, $0=$ not at all, $1=$ very small extent, $5=$ very high extent)

\begin{tabular}{|c|c|c|c|c|c|c|c|c|c|c|c|c|c|c|c|c|c|c|c|}
\hline \multirow{2}{*}{$\begin{array}{l}\text { Mecha- } \\
\text { nisms } \\
\text { sup- } \\
\text { porting } \\
\text { CBKF } \\
\end{array}$} & \multicolumn{2}{|c|}{ Anglo } & \multicolumn{2}{|c|}{ Latin E. } & \multicolumn{2}{|c|}{ Nordic } & \multicolumn{2}{|c|}{$\begin{array}{l}\text { Ger- } \\
\text { manic }\end{array}$} & \multicolumn{2}{|c|}{$\begin{array}{l}\text { East. } \\
\text { E. }\end{array}$} & \multicolumn{2}{|c|}{ South.A. } & \multicolumn{2}{|c|}{$\begin{array}{l}\text { Conf. } \\
\text { A. }\end{array}$} & \multicolumn{2}{|c|}{$\begin{array}{l}\text { Mid. } \\
\text { East }\end{array}$} & \multicolumn{3}{|l|}{ All } \\
\hline & I & II & I & II & I & II & I & II & I & II & I & II & I & II & I & II & I & II & IQR \\
\hline (1) & 64 & 4 & 38 & 3 & 61 & 4 & 48 & 3 & 40 & 3 & 67 & 4 & 33 & 2 & 0 & 2.5 & 49 & 4 & 1 \\
\hline (2) & 70 & 4 & 50 & 3.5 & 61 & 4 & 55 & 4 & 20 & 3 & 33 & 3 & 44 & 3 & 50 & 3.5 & 44 & 4 & 1 \\
\hline (3) & 42 & 3 & 35 & 3 & 43 & 3 & 35 & 3 & 40 & 3 & 67 & 4 & 44 & 3 & 50 & 3.5 & 38 & 3 & 2 \\
\hline (4) & 45 & 3 & 18 & 1.5 & 32 & 3 & 24 & 1.5 & 20 & 3 & 33 & 3 & 11 & 1 & 0 & 1.5 & 27 & 2 & 3 \\
\hline (5) & 58 & 4 & 23 & 2 & 50 & 3.5 & 16 & 2 & 20 & 3 & 33 & 1 & 11 & 1 & 0 & 1.5 & 29 & 2 & 3 \\
\hline (6) & 36 & 3 & 18 & 2 & 25 & 2 & 14 & 2 & 40 & 3 & 33 & 1 & 22 & 1 & 0 & 1.5 & 21 & 2 & 2 \\
\hline (7) & 33 & 3 & 38 & 3 & 36 & 3 & 26 & 3 & 80 & 4 & 33 & 2 & 22 & 1 & 0 & 3 & 31 & 3 & 3 \\
\hline (8) & 88 & 5 & 55 & 4 & 86 & 5 & 67 & 4 & 40 & 3 & 67 & 4 & 55 & 4 & 50 & 3.5 & 70 & 4 & 2 \\
\hline (9) & 58 & 4 & 53 & 4 & 54 & 4 & \begin{tabular}{|l|}
49 \\
\end{tabular} & 3.5 & 20 & 3 & 33 & 3 & 67 & 4 & 0 & 2.5 & 51 & 4 & 1 \\
\hline (10) & 48 & 3 & 29 & 2 & 39 & 3 & 35 & 3 & 40 & 3 & 33 & 3 & 33 & 2 & 0 & 2.5 & 36 & 3 & 3 \\
\hline (11) & 39 & 3 & 23 & 3 & 50 & 3.5 & 30 & 2 & 60 & 4 & 33 & 2 & 22 & 2 & 0 & 3 & 33 & 3 & 2 \\
\hline (12) & 42 & 3 & 47 & 3 & 57 & 4 & 39 & 3 & 60 & 4 & 0 & 2 & 44 & 3 & 50 & 3.5 & 44 & 3 & 2 \\
\hline (13) & 42 & 3 & 15 & 3 & 32 & 3 & 22 & 2 & 40 & 2 & 33 & 3 & 22 & 2 & 0 & 2.5 & 26 & 3 & 3 \\
\hline (14) & 70 & 4 & 38 & 3 & 68 & 4 & 62 & 4 & 60 & 4 & 33 & 3 & 44 & 3 & 0 & 1.5 & 58 & 4 & 2 \\
\hline (15) & 61 & 4 & 44 & 3 & 64 & 4 & 55 & 4 & 80 & 5 & 0 & 2 & 44 & 3 & 50 & 2.5 & 54 & 4 & 2 \\
\hline (16) & 79 & 4 & 44 & 3 & 71 & 4 & 71 & 4 & 60 & 5 & 0 & 3 & 56 & 4 & 50 & 2.5 & 65 & 4 & 2 \\
\hline
\end{tabular}

Source: own study

To identify mechanisms in terms of which cultural clusters significantly differed, a Kruskal-Wallis test was used. It was found that 9 out of 13 mechanisms were utilized at similar levels across all clusters, whereas significant differences occurred in cases of:

(1) e-learning programs at $\mathrm{p}=0.006(\mathrm{H}=19.707$, df:7, $\mathrm{N}=200)$; 
(2) virtual teams at $\mathrm{p}=0.0006(25.484,7,197)$;

(3) discussions via ICT at $\mathrm{p}=0.015(17.357,7,198)$;

(4) e-mentoring/e-coaching at $\mathrm{p}=0.075(12.868,7,197)$.

It also occurred that clusters varied in terms of HRM focus on knowledge sharing/teaching, in particular differences pertaining to: (1) recruitment policies was significant at $\mathrm{p}=0.017$ (17.047, 7, 199), (2) appraisal and reward policies at $\mathrm{p}=0.016(17.137,7,200)$, and (3) HRD initiatives/programs at $\mathrm{p}=0.003(21.226,7$, 200).

To obtain a detailed picture of clusters' specificity each cluster ${ }^{14}$ was compared with the rest of the sample using contingency tables, Pearson's Chi-Square test, and the UMW test. The former were applied to compare the proportion of companies (in a given cluster and in the rest of sample) declaring at least rather high usage of specific mechanisms, while the UMW test allowed to identify significant differences in average level of their usage. Results of these comparisons are shown in Table 3.

Table 3. Differences in usage of mechanisms supporting CBKF between particular clusters compared to the rest of the sample.

\begin{tabular}{|c|c|c|c|c|}
\hline CLUSTERS & ANGLO & LATIN E. & NORDIC & GERMANIC \\
\hline $\begin{array}{l}\text { Database of } \\
\text { good practices }\end{array}$ & $\begin{array}{l}\text { Higher level } \\
\mathrm{p}=0.046\end{array}$ & - & - & - \\
\hline $\begin{array}{l}\text { E-learning } \\
\text { programs }\end{array}$ & $\begin{array}{l}\text { Higher level } \\
\mathrm{p}=0.002 \\
\text { Higher } \\
\text { proportion } \\
\mathrm{X} 2=6.829, \mathrm{df}: 1, \\
\mathrm{p}=0.009\end{array}$ & - & $\begin{array}{l}\text { Higher level } \\
\mathrm{p}=0.050\end{array}$ & $\begin{array}{l}\text { Lower level } \\
\mathrm{p}=0.020\end{array}$ \\
\hline $\begin{array}{l}\text { Intern. virtual } \\
\text { teams }\end{array}$ & $\begin{array}{l}\text { Higher level } \\
\mathrm{p}=0.0006 \\
\text { Higher } \\
\text { proportion } \\
\mathrm{X} 2=15.674, \mathrm{df}: 1, \\
\mathrm{p}=0.00008\end{array}$ & - & $\begin{array}{l}\text { Higher level } \\
\mathrm{p}=0.006 \\
\text { Higher } \\
\text { proportion } \\
\mathrm{X} 2=6.973, \mathrm{df}: 1, \\
\mathrm{p}=0.008\end{array}$ & $\begin{array}{l}\text { Lower level } \\
\mathrm{p}=0.004 \\
\text { Lower proportion } \\
\mathrm{X} 2=11.858, \mathrm{df}: 1, \\
\mathrm{p}=0.0006\end{array}$ \\
\hline $\begin{array}{l}\text { E-coaching/ } \\
\text { e-mentoring }\end{array}$ & $\begin{array}{l}\text { Higher level } \\
\mathrm{p}=0.012 \\
\text { Higher } \\
\text { proportion } \\
\mathrm{X} 2=5.623, \mathrm{df}: 1, \\
\mathrm{p}=0.018\end{array}$ & - & - & $\begin{array}{l}\text { Lower level } \\
\mathrm{p}=0.017 \\
\text { Lower proportion } \\
\mathrm{X} 2=4.516, \mathrm{df}: 1, \\
\mathrm{p}=0.034\end{array}$ \\
\hline
\end{tabular}

14 Due to insufficient number of entities belonging to Eastern European, Southern Asian, Confucian Asian and Middle Eastern clusters, it was impossible to obtain reliable and statistically significant results by such in-pair comparisons. 


\begin{tabular}{|c|c|c|c|c|}
\hline $\begin{array}{l}\text { Cross-border } \\
\text { teams }\end{array}$ & - & - & $\begin{array}{l}\text { Higher } \\
\text { proportion } \\
X 2=3.979, \text { df:1, } \\
p=0.046\end{array}$ & - \\
\hline $\begin{array}{l}\text { Coaching/ } \\
\text { mentoring }\end{array}$ & $\begin{array}{l}\text { Higher level } \\
\mathrm{p}=0.05 \\
\text { Higher } \\
\text { proportion } \\
\mathrm{X} 2=5.541, \mathrm{df}: 1, \\
\mathrm{p}=0.019\end{array}$ & - & - & \\
\hline $\begin{array}{l}\text { Virtual corp. } \\
\text { CoP }\end{array}$ & - & - & - & - \\
\hline $\begin{array}{l}\text { Discussions via } \\
\text { ICT }\end{array}$ & $\begin{array}{l}\text { Higher level } \\
\mathrm{p}=0.036 \\
\text { Higher } \\
\text { proportion } \\
\mathrm{X} 2=6.016, \mathrm{df}: 1, \\
\mathrm{p}=0.014\end{array}$ & $\begin{array}{l}\text { Lower level } \\
\mathrm{p}=0.026 \\
\text { Lower proportion } \\
\mathrm{X} 2=4.495, \mathrm{df}: 1, \\
\mathrm{p}=0.034\end{array}$ & $\begin{array}{l}\text { Higher level } \\
\mathrm{p}=0.007 \\
\text { Higher } \\
\text { proportion } \\
\mathrm{X} 2=3.829, \mathrm{df}: 1 \text {, } \\
\mathrm{p}=0.05\end{array}$ & - \\
\hline $\begin{array}{l}\text { Recruitment } \\
\text { policy }\end{array}$ & - & $\begin{array}{l}\text { Lower level } \\
p=0.014\end{array}$ & - & - \\
\hline $\begin{array}{l}\text { Appraisal/ } \\
\text { rewards } \\
\text { systems }\end{array}$ & - & $\begin{array}{l}\text { Lower level } \\
\mathrm{p}=0.049\end{array}$ & - & - \\
\hline $\begin{array}{l}\text { HRD } \\
\text { programs/ } \\
\text { initiatives }\end{array}$ & - & $\begin{array}{l}\text { Lower level } \\
\mathrm{p}=0.002\end{array}$ & - & - \\
\hline
\end{tabular}

Source: own study

Given the results displayed in Tables 2 and 3, it can be found that:

- Majority of subsidiaries in cluster 'Anglo' used intensively ICT-based solutions, and most often support CBKF by: (1) mechanisms ensuring access to structured knowledge, i.e. databases and repositories, and (2) mechanisms based on virtual interactions, i.e. virtual teams, discussions and consulting experts from corporate database. These entities declared significantly higher usage of many practices based on virtual interactions, e-learning, and cross-border coaching/mentoring.

- Similar practices occurred in a majority of Nordic subsidiaries, however, they also relied on mechanisms enabling direct contacts such as delegating employees for international assignments (IAs) or cross-border teams. Compared with the others they demonstrated significantly higher usage of e-learning programs, international virtual teams, discussions via ICT, and cross-border teams.

- Every second Latin and Germanic subsidiary facilitated CBKF through voluntary virtual interactions (discussions and consulting corporate experts), and access to databases/repositories. However, in the Latin cluster internal HR practices to a significantly lower extent emphasised knowledge sharing/ 
teaching, whereas the Germanic cluster differed from others with respect to lower usage of mechanisms based on compulsory virtual interactions, and e-learning programs.

- In the least numerous clusters, i.e. Eastern European, Southern Asian Southern Asian and Middle East, attempts to delineate common practices might lead to dubious conclusions, and therefore further research is recommended.

\section{Final Remarks}

Despite limitations related to the scope of this study, characteristics of the sample (inter alia, unequal sizes of clusters due to random sampling), the choice of a single-informant approach, and introducing such categories as country clusters (which results in replacing a complex picture of reality with simplistic categories), it still allows to draw several conclusions pertaining to considered practices in Poland-based foreign subsidiaries.

First, there were many similarities between mechanisms applied by these entities across distinguished clusters. A prevailing practice occurring in these companies relied on supporting CBKF by extensive usage of discussions via ICT and providing access to databases, which in turn, corresponds with findings from previous studies conducted in Poland, i.e. overemphasising a "technological" aspect in KM, a focus on explicit knowledge, and usage of less advanced ICT-based tools [Glińska-Neweś A. 2007, pp.260-261, Gruszczyńska-Malec G., Rutkowska M. 2013, pp. 209-210]. These results suggest that subsidiaries demonstrate local responsiveness of MNCs they belong to (i.e. adjustment to local practices concerning knowledge flow) and/ or develop their own activities in a relatively independent manner.

Second, unlike Polish domestic enterprises (in the Gruszczyńska-Malec and Rutkowska' study) foreign subsidiaries developed HRM practices which appreciate behaviours aimed to knowledge sharing/teaching ${ }^{15}$. This in turn, can prove that Poland-based subsidiaries try to develop an integrated approach, which consists in coordination/interrelation of KM and HRM activities.

Finally, this study revealed significant differences in CBKF-related practices (which is congruent with the assumption concerning occurrence of country-oforigin effect) between subsidiaries belonging to diverse clusters. One, a wide range of ICT-based tools in Anglo and Nordic groups, and rather poor in Germanic and Latin, where most frequent practices were access to repositories, and virtual interactions initiated by geographically dispersed employees. Two, an important role of direct contacts in Nordic cluster, and three, a weaker HRM focus on knowledge sharing/teaching in the Latin European cluster compared with other companies.

Hence, the suggested earlier need to introduce intercultural aspects in research on knowledge flow in MNCs received a strong support from these findings, whose

15 Except for Latin Europe, for whom these practices occurred at moderate level. 
extension (in future studies) should cover: (1) a more profound diagnosis of HRM practices aimed to support CBKF in Poland-based subsidiaries, (2) exploring practices specific for country clusters which were underrepresented in this study, (2) comparing practices reported for Poland-based subsidiaries in Germanic, Nordic, Latin European and Anglo clusters with their equivalents located in other countries (to determine whether differences identified by in-pair comparisons and similarities observed between pairs: Anglo-Nordic, and Germanic-Latin are specific only for Poland or do they also occur in other locations), (3) identifying reasons of introducing and withdrawing specific mechanisms of CBKF in different cultural contexts (which offers a more complex picture of the cultural contexts' impact).

\section{References}

Bonache, J., and Dickmann, M. (2008), Transfer of strategic know-how in MNCs: mechanisms, barriers and initiatives, in: Dickmann, M., Brewster, C., and Sparrow, P. (eds.) International Human Resource Management. A European perspective, London/ New York: Routledge,.

Dickmann, M., and Müller-Carmen, M. (2006) 'Configuring for IHRM innovation: a typology and empirical assessment of strategies, structures and processes of international HRM', International Journal of Human Resource Management, 17(4), pp. 580-601.

Evans, P., Pucik, V., and Björkman, I. (2011) The Global Challenge. International Human Resource Management, New York:McGraw-Hill.

Glińska-Neweś, A. (2007) Kulturowe uwarunkowania zarz̨adzania wiedza w przedsiebiorstwie, Toruń: Wyd. Dom Organizatora.

Gruszczyńska-Malec, G., and Rutkowska, M. (2013) Strategie ₹arzadzania wiedఇa, Warszawa: PWE.

Gupta, A.K., and Govindarajan, V. (2000) 'Knowledge flows within multinationals corporations', Strategic Management Journal, vol. 21 (4), pp. 473-496.

Harzing, A.W., and Sorge, A.M. (2003) 'The relative impact of country-of-origin and universal contingencies on internationalization strategies and corporate control in multinational enterprises: Worldwide and European perspectives', Organization Studies, 24(2), pp.187-214.

House, R.J., Hanges, P.J., Javidan, M., Dorfman, P., and Gupta, V. (eds.) (2004) Leadership, culture, and organizations: The GLOBE study of 62 societies, Thousand Oaks, CA: Sage Publications, Inc.

Javindan, M., Stahl, G.K., Brodbeck, F., and Wilderon C.P.M. (2005) 'Cross-border transfer of knowledge: Cultural lessons from Project GLOBE', Academy of Management Executive, vol. 19 (2), pp. 59-76.

Kordel, P, Kornecki, J., Kowalczyk, A., Krawczyk, K., Pylak, K., and Wiktorowicz, J. (2010) Inteligentne organizacje - zarządzanie wiedzą i kompetencjami pracowników, Warszawa: 


\section{Wyd. Polska Agencja Rozwoju Przedsiębiorczości}

Kostova, T. (1999) 'Transnational transfer of strategic organizational practices: a contextual perspective', Academy of Management Review, vol. 24 (2), pp.308-324.

Li, L., Barner-Rasmussen, W., and Björkman, I. (2007) 'What Difference Does the Location Make?: A Social Capital Perspective on Transfer of Knowledge from Multinational Corporation Subsidiaries Located in China and Finland', Asia Pacific Business Review, vol. 13 (2), pp. 233-249.

Lin, C.Y., (2006) 'Influences of culture on inter-unit knowledge transfer processes within multinational corporations', The Journal of Global Business Management, vol.2, pp. 2431.

Nonaka, I. and Toyama, R. (2003) 'The knowledge-creating theory revisited: Knowledge creation as a synthesizing process', Knowledge Management Research and Practice, vol. 1, pp. $2-10$.

Nonaka, I., Toyama, R., and Hirata, T. (2008) Managing Flow. A Process Theory of the Knowledge-Based Firm, London/New York: Palgrave MacMillan.

Noorderhaven N., and Harzing A.-W. (2003) 'The "country-of-origin effect" in multinational corporations: Sources, mechanisms and moderating conditions', Management International Review, vol. 43, special issue 2, pp. 47-66.

Pauleen, D.J., Wu, L.-L., and Dexter, S. (2007) Exploring the Relationship between National and Organizational Culture, and Knowledge Management, in Pauleen, D.J. (ed.) Cross-cultural Perspective on Knowledge Management, Westport/London: Libraries Unlimited.

Płoszajski, P. (ed.) (2011) Zarządzanie wiedzą w Polsce. Bilans doświadczeń (research report) http://www.knowledgeboard.com/download/1465/Raport-Zarz-dzanieWiedzBilans-do-wiadcze-.pdf [30 September 2011].

Przytuła, S. (2014) 'Postrzeganie ekspatriantów przez lokalną kadrę menedżerską - korzyści i problemy we wzajemnej współpracy’, Zarządzanie Zasobami Ludzkimi, vol. 6 (101), pp. 87-104.

Purgał-Popiela, J. (2015b) Role of international assignments in knowledge flow in small and medium companies with foreign ownership, Proceeding of the 5th International Conference on Management 2015. Management, leadership and strategy for SMEs' competitiveness, DOI:10.17626/dBEM.ICoM.P00.2015.p009.

Rozkwitalska, M. (2011) Bariery w zarządzaniu międzykulturowym. Perspektywa filii zagranicznych korporacji transnarodowych, Warszawa: Oficyna a Wolters Kluwer business.

Sparrow, P. (2006) 'Global knowledge management and HRM', in Stahl, G.K., and Björkman, I. (eds.) Handbook of Research in International Human Resource Management, Cheltenham/Northhampton; Edward Elgar.

Stankiewicz, M.J. (ed.) (2006) Zarządzanie wiedzą jako kluczowy czynnik międzynarodowej konkurencyjności przedsiębiorstwa, Toruń: Dom Organizatora.

Stor, M. (2011) Strategiczne międzynarodowe zarządzanie zasobami ludzkimi, Prace Nau- 
kowe nr 154, Wrocław: Wyd. Uniwersytetu Ekonomicznego.

Zhu, Z. (2004) 'Knowledge management: towards a universal concept or cross-cultural contexts?', Knowledge Management Research \& Practice, vol. 2 (2), pp. 67-79. 